\section{Peningkatan Hasil Belajar Siswa Pada Materi Gaya Melalui Metode Demonstrasi Pada Siswa Kelas V Madrasah Ibtidaiyah Yaminas Loppe Kabupaten Luwu}

\author{
Malasari \\ Institut Agama Islam Negeri Palopo \\ Malasarisasri1997@gmail.com
}

\begin{abstract}
This study aims to improve science learning outcomes in the style material of fifth grade students of Yaminas Loppe Madrasah Ibtidaiyah Luwu Regency. The study was a type of Classroom Action Research (CAR) conducted in class V of Madrasah Ibtidaiyah Yaminas Loppe in Bupon Subdistrict, Luwu Regency with a total of 15 students. Data collection techniques used are observation, learning outcome tests, documentation. The results of this study indicate that the application of the demonstration method in science subjects style material can improve student learning outcomes of class V. This is shown through the acquisition of observations of student and teacher activities and test results that indicate an increase. The results of observation of student activities increased from 76.51 in the first cycle to 92.42 in the second cycle. Likewise, the observation of teacher activities also increased from 80 in the first cycle to 93.33 in the second cycle. Both the first and second cycle categories increased from good to very good. While the average test results increased from 61 included in the less category in the first cycle to 75.67 included in the sufficient category in the second cycle. Thus, indicators of success in research on classroom action are achieved. Thus by applying the demonstration method can improve science learning outcomes in elementary schools, especially material style material.
\end{abstract}

Keywords: Learning outcomes, Style Material, Demonstration Method

\section{A. Pendahuluan}

Pendidikan dipandang usaha sadar dan terencana untuk meningkatkan kualitas pendidikan yang menjadi pondasi utama suatu insan. Satu perubahan yang terjadi akan menyebabkan perubahan berikutnya dan akan berguna bagi kehidupan atau proses belajar berikutnya(Slameto, 2013:3). Hal ini dikarenakan melalui pendidikan seseorang akan bermutu, berwawasan dan berilmuPembelajaran merupakan suatu proses yang terdiri dari kombinasi dua 
aspek, yaitu: belajar tertuju kepada apa yang harus dilakukan oleh siswa, mengajar beorientasi pada apa yang harus dilakukan oleh guru sebagai pemberi pelajaran. Kedua aspek ini akan berkolaborasi secara terpadu menjadi suatu kegiatan pada saat terjadi interaksi antara guru dengan siswa, antara siswa dengan siswa di saat pembelajaran sedang berlangsung (Asep Jihad dan Abdul Haris, 2013: 11). Pengajar dalam dunia pendidikan harus mampu membuat siswa kreatif dan inovatif dalam membentuk pola pikir siswa didalam pembelajaran. Dalam konteks pendidikan multikultural yang berkarakter, pengajar harus mampu memberikan contoh-contoh pengaplikasian nilai dalam tingkah laku kesehariannya (Rustan, 2010). Hal ini akan mengilhami siswa untuk membentuk karakternya sesuai sesuai dengan kompetensi yang diinginkannya". Dalam dunia pendidikan diperkenalkan terdapat beragam metode pembelajaran yang dapat diterapkan kepada peserta didik. Menurut Syamsu S (2017:23) Metode pembelajaran adalah cara yang digunakan guru untuk menyampaikan bahan pelajaran kepada peserta didik guna mencapai tujuan yang telah di tetapkan. Memilih metode yang akan digunakan dalam mengajar harus disesuaikan dengan rumusan tujuan pembelajaran. Metode pembelajaran yang digunakan oleh guru harus memberi kemungkinan agar siswa dapat ikut aktif dalam pembelajaran yang menyenangkan sehingga siswa dapat belajar dengan nyaman.

Belajar dapat diartikan sebagai suatu aktifitas yang dilakukan seseorang dengan sengaja dalam keadaan sadar untuk memperoleh suatu konsep, pemahaman, atau pengetahuan baru sehingga memungkinkan seseorang terjadinya perubahan perilaku yang relatif tetap baik dalam berfikir, merasa, maupun dalam bertindak (Ahmad Susanto, 2016:4). Sejalan dengan pengertian tersebut, ahli pendidikan modern merumuskan belajar sebagai suatu bentuk pertumbuhan atau perubahan dalam diri seseorang yang dinyatakan dalam caracara bertingkah laku yang baru berkat pengalaman dan latihan (zainal Aqib, 2010:42). Pembelajaran merupakan proses sistematis dan melibatkan banyak komponen yang tidak bersifat parsial tetapi harus berjalan secara teratur, saling bergantung, komplementer, dan berkesinambungan. Oleh karena itu diperlukan pengelolaan pembelajaran. Proses pembelajaran yang baik selain diawali dengan perencanaan yang bijak, juga didukung dengan pengembangan strategi yang mampu membelajarkan siswa (Khanifatul, 2013: 26). Hasil belajar adalah kemampuan-kemampuan yang dimiliki siswa setelah ia menerima pengalaman belajarnya. Horward Kingsley (dalam Nana Sudjana) membagi tiga macam hasil belajar, yakni (a) keterampilan dan kebiasaan, (b) pengetahuan dan pengertian, (c) sikap dan cita-cita sedangkan Gagne (dalam Nana Sudjana) membagi lima kategori hasil belajar, yakni (a) informasi verbal, (b) keterampilan intelektual, (c) strategi kognitif, (d) sikap, (e) keterampilan motoris (Nana Sudjana, 2006: 22).

Hasil belajar siswa merupakan hasil kegiatan dari belajar dalam bentuk pengetahuan sebagai akibat dari perlakuan atau pembelajaran yang dilakukan oleh siswa. Dengan kata lain, hasil belajar siswa merupakan apa yang diperoleh siswa dari proses belajar (Hamzah B uno, 2007: 139). Darmodjo (1992) mengemukakan bahwa "IPA sangat diperlukan oleh siswa sekolah dasar, karena 
pembelajaran IPA dapat memberikan masukan bagi pencapaian pendidikan dasar selanjutnya". Ilmu Pengetahuan Alam berfungsi untuk memberikan pengetahuan dari berbagai jenis dan kejadian lingkungan alam dan lingkungan buatan dalam kaitannya dengan pemanfaatan dengan kehidupan sehari-hari. Hal ini sejalan dengan Abruscato, (Khairuddin dan Soedjono, 2005) yang mengungkapkan bahwa pembelajaran IPA di SD untuk mengembangkan, (1) kognitif siswa, (2) mengembangkan afektif siswa, (3) mengembangkan psikomotorik siswa, (4) mengembangkan kreatifitas siswa, (5) melatih siswa untuk berpikir kritis. Mata pelajaran IPA di SD sangat mendukung terbentuknya siswa yang aktif dan kreatif dalam pembelajaran serta mendukung sifat anak yang selalu ingin tahu tentang proses gejala-gejala alam yang terjadi di sekitar secara sistematis. Dalam pembelajaran IPA agar lebih bermakna dan melekat pada diri siswa maka pembelajaran harus memiliki metode yang tepat dan dapat menciptakan situasi yang menyenangkan bagi siswa, dan dapat membangkitkan keatifan siswa di dalam kegiatan pembelajaran, yang bermuara pada optimalnya hasil pembelajaran mata pelajaran IPA itu sendiri. Hakikat pembelajaran sains yang didefenisikan sebagai ilmu tentang alam yang dalam bahasa Indonesia disebut dengan Ilmu Pengetahuan Alam, dapat diklasifikasikan menjadi tiga bagian, yaitu: ilmu pengetahuan alam sebagai produk, proses, dan sikap. Dari ketiga komponen IPA ini, Sutrisno (dalam Ahmad Susanto) menambahkan bahwa IPA juga sebagai prosedur dan IPA sebagai teknologi.( Ahmat Susanto, 2016 : 167). Pendidikan sains di tingkat Sekolah Dasar bermanfaat bagi siswa untuk mempelajari diri sendiri dan alam sekitar. Dalam kegiatan belajar mengajar sains khususnya IPA dengan melatih keterampilan proses tidak diharapkan setiap siswa akan menjadi saintis, melainkan mampu mengemukakan idenya bahwa memahami IPA bergantung pada kemampuan memandang dan bergaul dengan alam menurut cara-cara yang diperbuat oleh ilmuan. Kegiatan belajar mengajar dengan melatih keterampilan proses kepada siswa dapat dilaksanakan dengan keyakinan bahwa IPA merupakan alat yang sangat potensial untuk membantu kepribadian siswa. Kepribadian siswa dikembangkan merupakan prasyarat untuk melangkah ke jalur profesi apapun yang di minatinya (Trianto, 2015: 149). Ada beberapa jenis metode pembelajaran yang digunakan oleh guru dalam proses belajar mengajar di kelas, yaitu metode ceramah, diskusi, demonstrasi, simulasi, dan resitasi. Oleh karena itu, guru dapat memilih metode pembelajaran yang tepat sesuai kondisi siswanya sehingga tujuan pembelajaran dapat tercapai. Penggunaan metode demonstrasi mampu mengkomunikasikan sesuatu yang ingin disampaikan oleh pemberi kepada penerima. Oleh karena itu dalam merancang proses belajar hendaknya dipilih metode yang benar-benar efektif dan efisien atau merancang metode sendiri sehingga dapat menyampaikan pesan pembelajaran, yang akhirnya terbentuk kompetensi tertentu dari siswa. Metode yang dimaksud dalam penelitian ini adalah metode demonstrasi. Berikut dipaparkan beberapa pengertian metode demonstrasi, (Syaiful Bahri Djamarah dan Aswan Zain, 2006: 90) mengemukakan bahwa metode demonstrasi adalah cara penyajian pelajaran dengan meragakan atau mempertunjukkan kepada siswa suatu proses situasi atau benda tertentu yang sedang dipelajari, baik sebenarnya ataupun tiruan, 
yang sering disertai dengan penjelasan lisan.(Wina Sanjaya,2006: 153) mengemukakan metode demonstrasiadalah metode penyajian pelajaran dengan memperagakan dan mempertunjukkan kepada siswa tentang suatu proses, situasi atau benda tertentu, baik sebenarnya atau hanya sekedar tiruan. Ahmad Sabri (dalam Syamsu S) memberikan kriteria guru dalam memilih dan menggunakan metode pembelajaran agar tujuan pembelajaran dapat dicapai secara efektif dan efesien, yaitu: (a) Metode yang digunakan harus dapat membangkitkan minat motivasi belajar peserta didik. (b) Metode yang digunakan dapat merangsang keinginan peserta didik untuk belajar lebih lanjut. (c) Metode yang digunakan harus dapat memberikan kesempatan bagi peserta didik untuk mewujutkan hasil karya, (d) Metode yang digunakan harus dapat menanamkan dan mengembangkan nilai-nilai dan sikap peserta didik; (Syamsu S 2015: 93). Metode yang digunakan harus dapat mendidik peserta didikuntuk memperoleh pengetahuan melalui usaha sendiri.

Gaya merupakan dorongan atau tarikan yanag dapat mempengaruhi gerak benda. Gaya dapat mengubah letak atau keadaan suatu benda suatu benda. Jadi, gaya merupakan faktor yang mempengaruhi gerak dan letak atau keadaan suatu benda (Abitur A, 20004:69). Adapun macam-macam gaya adalah (1) gaya magnet (2) gaya grafitasi(3)gaya gesek(4) gaya pegas).

Pembelajaran dikatakan berhasil selain ditentukan oleh kemampuan guru dalam menentukan metode dan alat yang digunakan dalam pengajaran, juga ditentukan oleh minat belajar siswa. Seperti contoh kasus yang terdapat di kelas V Madrasah Ibtidaiyah Yaminas Loppe, diperoleh informasi bahwa terdapat beberapa kekurangan dalam proses pembelajaran IPA di kelas diantaranya siswa kurang memperhatikan materi yang diberikan guru dan malu bertanya tentang materi yang belum dimengerti sehingga menghasilkan banyak nilai siswa yang tidak memenuhi nilai standar KKM. Selain itu, dalam proses pembelajaran IPA guru seringkali menyampaikan materi pembelajaran dengan hanya satu metode saja yaitu metode ceramah, guru tidak memanfaatkan media yang ada padahal seperti yang diketahui bahwa untuk meningkatkan hasil belajar siswa, perlu adanya penggunaan media belajar dan model pembelajaran yang tepat. Suatu kegiatan belajar mengajar tidak dapat mencapai tujuan yang diharapkan tanpa adanya peran metode pembelajaran yang baik. Oleh karena itu, diperlukan suatu metode agar tujuan yang diharapkan dapat terwujud dengan baik. Dalam Sering kali hasil yang diharapkan dalam kegiatan belajar mengajar kurang maksimal, karena tidak efektifnya metode yang digunakan dalam pembelajaran. Dalam penelitian ini penulis melakukan uji coba penerapan metode demonstrasi sebagai upaya peningkatan hasil belajar IPA siswa kelas V Madrasah Ibtidaiyah Yaminas Loppe Kabupaten Luwu semester ganjil tahun pelajaran 2017/2018. Hal ini berdasar kepada manfaat PTK yang penulis harapkan dapat mengatasi atau meminimalkan permasalahan yang terjadi di lapangan yang dianggap sebagai tugas utama guru. Dalam hal ini peneliti mengambil jenis penelitian PTK karna pada tahap penelitian PTK pembelajarannya bukan hanya satu kali atau dua kali pertemuan tetapi sampai hasil yang diinginkan tercapai sehingga pada penelitian ini menggunakan metode demonstrasi, di mana metode ini sangat berguna dalam materi gaya karna dibutuhkan praktek yang banyak yang disertai 
dengan penjelasan agar siswa lebih mudah memahami pelajar tersebut.Berdasarkan pernyataan tersebut, maka penulis tertarik untuk melakukan penelitian dan membahasnya dalam bentuk skripsi yang berjudul "Peningkatan Hasil Belajar IPA pada Materi Gaya melalui Metode Demostrasi Pada Siswa kelas V Madrasah Ibtidaiyah Yaminas Loppe Kabupaten Luwu".

\section{B. Metode Penelitian}

Penelitian ini merupakan penelitian tindakan kelas (PTK) atau action research. Masnur Muslich (2011:10) mengemukakan PTK merupakan penelitian yang bertujuan untuk memperbaiki dan meningkatkan kualitas pembelajaran serta membantu memberdayakan guru dalam memecahkan masalah pembelajaran di sekolah. penelitian tindakan kelas menggunakan jenis data kualitatif. Desain yang digunakan model Desain PTK Model Kemmis dan Mc Taggart. Selanjudya model kemmis danh Taggart yang diguanakan yaitu pada komponen prencanaan, pelakasanaan, observasi dan refleksi yang dilaksanaakan dalam dua siklus. Tiap siklus dilaksanakan sesui dengan perubahan yang ingin dicapai serta apa yang telah didesain dlam faktor yang diselidiki. Subjek penelitian dalam penelitian tindakan kelas ini adalah siswa/i kelas V MI Yaminas Loppe kecamatan Bupon Kabupaten Luwu yang berjumlah 15 orang.

Sumber data dalam peniltian ini yaitu: (1) Data Primer data yang diperoleh langsung oleh peneliti yang berupa hasil tes belajar siswa dan hasil observasi dengan pihak sekolah terkhususnya guru kelas V; (2) Data sekunder adalah data yang diperoleh dari data tertulis berupa profil sekolah, data guru, data siswa, serta sarana dan prasrana yang ada di sekolah tersebut yang dibutuhkan kelengkapan dalam penelitian. Untuk mengumpulkan data dalam penelitian ini dilakukan dengan tes, wawancra, pengamatan, dan dokumentasi. Analisis data dalam penelitian ini dilakukan selama dan setelah penelitian. Dalam penelitian ini, peneliti hanya menyerahkan rancangan tes (instrument) kepada guru kelas V MI Yaminas Loppe atas nama M. Saing, S.Pd.I. untuk memvalidasi. Validator diberikan lembar validasi setiap instrumen untuk diisi dengan tanda centang $(\sqrt{ })$ pada skala likert 1 - 4 dengan ketentuan. Seperti halnya validitas, untuk mengetahui ketetapan reliabilitas suatu tes juga pada dasarnya dilihat kesejajaran hasil. Teknik korelasi product moment juga dapat digunakan untuk mengetahui kesejajaran hasil dalam reliabilitas tes (Suharsimi Arikunto 2017: 104) .Selanjutnya berdasarkan lembar validasi yang telah diisi oleh validator tersebut dapat ditentukan validitasnya, (Saifuddin Azwar, 2013: 113) dengan rumus statistic Aiken's berikut: $V=\frac{\sum S}{n(c-1)}$ Untuk hasil observasiaktifitas siswa dianalisis secara kualitatif yang diolah dengan teknik persentase dengan menghitung persentasi siswa yang terlihat aktif, dengan menggunakan rumus berikut $: \mathrm{P}=\frac{F}{N} \times 100 \%$ (Anas Sudijono, 2017: 43). (2) analisai tes, Dalam Data hasil observasi selanjutnya dibandingkan dan ditentukan dengan taraf keberhasilan tindakan sebagai berikut: Interpretasi Kriteria Keberhasilan 80\% 100\% Sangat Baik 70\% - 79\% Baik 60\% - 69\% Cukup, 55\% - 59\% Kurang, < 55\% sangat kurang (I Ketut R Sudiarditha,2011: 40) Analisis Tes Untuk mengetahui 
hasil belajar IPA digunakan kriteria Interpretasi Kategori Hasil Belajar sebagai berikut: 90 - 100 Baik sekali 80-89 baik 70-79 cukup 0-69 sangat kurang.

\section{Hasil Penelitian}

\section{Deskripsi Proses Pembelajaran}

Menerapkan metode demonstrasi pada materi gaya pada siswa kelas V MI Yaminas Loppe Kabupaten Luwu dapat mengalami peningkatan melalui tahap prasiklu, siklus I dan sisklus II dan beberapa gambaran pelaksanaan mulai dari pra siklus, siklusI dan siklus II. Seperti gambararan a wal pra siklus Gambaran Kemampuan awal siswa Telah dikemukakan pada BAB sebelumnya yang berada pada BAB pendahuluan bahwa hasil belajar siswa V MI Yaminas Loppe Kabupaten Luwu masi tergolong rendah. Berdasarkan pra tindakan yang dilakuka oleh peneliti pada kelas V MI Yaminas Loppe Kabupaten Luwu yaitu permasalahan pada observasi awal yang peneliti temukan berdasarkan pengamatan saat pembelajaran berlangsung, siswa kurang memperhatikan materi yang diberikan guru dan malu bertanya tentang materi yang belum dimengerti sehingga menghasilkan banyak nilai siswa yang tidak memenuhi nilai standar KKM. Karna guru guru seringkali menyampaikan materi pembelajaran dengan hanya satu metode saja yaitu metode ceramah tanpa memanfaatkan media. Akibatnya siswa tidak mampu memahami pelajaran dengan baik. Untuk mengetahui sejauh mana kemampuan siswa terhadap materi yang diberikan yaitu dengan melakukan obsevasi dan memberikan tes awal.

Selanjunya Gambaran Hasil siklus I, Tindakan siklus I dilaksanakan sebanyak 3 kali pertemuan. Alokasi waktu setiap pertemuan adalah $(2 \times 35$ menit). Tindakan siklus I dilaksanakan sebanyak 3 kali pertemuan. Alokasi waktu setiap pertemuan adalah $(2 \times 35$ menit $)$. Penelitian dilakukan dengan penelitian tindakan kelas yang terdiri dari siklus-siklus dan pada setiap siklus terdiri dari 6 tahapan. Perencanaan yang telah dibuat terlebih dahulu dikonsultasikan dengan guru kelas V MI Yaminas Loppe Kabupaten Luwu yaitu M. Saing. S.pd.i., bahwa siklus I materi penelitian yang diajarkan yaitu materi gaya dengan menggunakan metode demonstrasi.selanjudya mengadakan refleksi yaitu membahas dan mengevaluasi kegiatan pembelajaran yang baru telah dilaksanakan. Refleksi dilakukan untuk mengetahui kekurangan atau kendala pada siklus I. Siklus II dilaksanakan selama 3 kali pertemuan, dengan 2 kali tatap muka dan 1 kali evaluasi dipertemuan akhir siklus. Guru melakukan langkahlangkah pembelajaran sesuai dengan RPP dengan berusaha memperbaiki kekurangan-kekurangan dalam proses pembelajaran yang dilakukan pada siklus I. Kegiatan pada siklus II ini adalah mengulang kembali kegiatan-kegiatan yang dilakukan pada siklus I dengan melakukan perbaikan-perbaikan yang masih dianggap kurang pada siklus I. data yang diperoleh pada proses pembelajaran dan menentukan apakah data yang telah diproses tersebut pada tahap siklus II hasilnya lebih dibandingkan data yang diperoleh pada siklus I.

\section{Peningkatan hasil belajar IPA pada materi gaya melalui metode demonstrasi}

Hasil prasiklus dari 15 siswa yang menjadi sampel sekaligus ikut dalam melakukan tes awal ternyata 4 siswa yang mendapat nilai termasuk kategori 
cukup, 11 siswa termasuk kategori kurang dan mendapatkan nilai rata-rata 57. nilai rata-rata siswa dengan menggunakan metode demonstrasi pada materi gaya adalah 61 pada tahap siklus I setelah menerapkan metode demonstrasidari 15 siswa 15 yang belum memenuhi standar ketuntasan dengan nilai KKM yaitu 75 dengan ketuntasan belajar 86,67\% dan 9 siswa mendapat nilai dibawah $>70$ dengan ketidaktuntasan belajar $13.33 \%$. Berdasarkan uji validitas diperoleh bahwa rata-rata penilaian instrumen tes siklus I sebesar 0,64 termasuk kategori "sedang/cukup" dan rata-rata penilaian instrumen tes siklus II sebesar 0,72 termasuk kategori "kuat/tinggi". Sedangkan berdasarkan uji reliabilitas menunjukkan bahwa tingkat kereliabelan tes siklus I sebesar 0,86 termasuk kategori "sangat tinggi" dan tes siklus II sebesar 0,92 termasuk kategori "sangat tinggi". Setelah tes dinyatakan valid dan reliabel, selanjutnya penulis melanjutkan pada tahap analisis data. diperoleh bahwa untuk hasil observasi aktifitas siswa mengalami peningkatan dari 76,51 pada siklus I menjadi 92,42 pada siklus II Teknik validitas yang digunakan dalam penelitian ini yaitu validitas isi. Hal ini dapat diketahui berdasarkan observasi yang dilakukan pada setiap pertemuan dari prasiklus, siklus I, dan siklus II. jika dikelompokkan dalam lima kategori maka dari 15 siswa yang menjadi sampel sekaligus ikut dalam tes evaluasi ternyata 13 siswa yang mendapat nilai termasukkategori Baik, 2 siswa termasuk dalam kategori. Penelitian dilakukan dengan penelitian tindakan kelas yang terdiri dari siklus-siklus dan pada setiap siklus terdiri dari 6 tahapan,(1 Jprencanaan tindakan siklus I,(2) pelaksanaan tindakan, Hasil belajar siswa pada pembelajaran gaya dengan menggunakan metode demonstrasi pada siswa keelas V Yaminas Loppe Kabupaten Luwu masih belum optimal karena hasil belajar peserta didik pada siklus I masih dengan rata-rata 61 dengan ketuntasan mencapai 67 dalam kategori kurang. Proses pembelajaran masih di dominasi oleh guru sehingga belum semua peserta didik terlihat aktif dalam mengikuti pembelajaran. (3) hasil analisais refleksi, Hasil analisis Refleksi yaitu membahas dan mengevaluasi kegiatan pembelajaran yang baru telah dilaksanakan. Refleksi dilakukan untuk mengetahui kekurangan atau kendala pada siklus I. Pada saat guru menjelaskan materi pembelajaran, masih banyak siswa yang tidak memperhatikan dengan baik, ada yang berbicara dan bercerita serta ada juga yang lebih asik bermain coretan dibukunya. Masih terdapat beberapa psiswa yang merasa bosan dengan kegiatan pembelajaran dan tidak memperhatikan materi pembelajaran. Guru kurang menggunakan metode untuk menarik perhatian siswa dan kurang memberi kesempatan kepada peserta didik untuk bertanya sehingga masih banyak siswa yang tidak memahami materi gayaDengan melihat kekurangan-kekurangan yang ada serta hasil tes siklus I yang belum mencapai indikator keberhasilan yang telah ditetapkan, maka diperlukan siklus II untuk meningkatkan hasil belajar siswa. Hasil evaluasi siklus II nilai rata-rata hasil belajar peserta didik diperoleh dengan rumus rata-rata: $\frac{1.135}{15}=75.67$ Dari 15 siswa yang mengikuti tes evaluasi siklus II terdapat 13 peserta didik yang memenuhi ketuntasan dengan nilai KKM yaitu 75 dengan ketuntasan belajar $86,67 \%$ dan 2 orang mendapat nilai di bawah 70 dengan ketidak tuntasan belajar 13.33 \%. Hasil analisis Refleksi Pada tahap ini data yang diperoleh pada proses pembelajaran dan menentukan apakah data yang telah 
diproses tersebut pada tahap siklus II hasilnya lebih dibandingkan data yang diperoleh pada siklus I. Dalam kegiatan pembelajaran pada siklus II, guru telah berupaya memperbaiki penggunaan metode demonstrasi dalam menyampaikan materi gaya media yang ada sehinggah siswa mudah memahami materi gaya oleh. Hasilnya siswa pun lebih fokus dan lebih menikmati pelajaran dengan baik. Peserta didik menjadi lebih aktif dan tidak malu lagi untuk bertanya mengenai materi yang belum dipahama. Siswa juga lebih mudah menjawab soal yang diberikan dengan bimbingan guru kepada siswa dengan baik.

Dalam analisis hasil observasi ini peneliti melakukan pengamatan terhadap siswa selama proses pembelajaran yang meliputi indikator pelaksanaan demonstrasi; untuk hasil observasi aktifitas siswa mengalami peningkatan pada setiap pertemuan dengan rata-rata pencapaian pada siklus I sebesar 76,51. Perolehan ini jika disesuaikan dengan 3.3 diperoleh rata-rata pencapaian aktivitas siswa pada siklus I berada dalam kategori baik. Sedangkan rata-rata pencapaian pada siklus II sebesar 92,42. Perolehan ini jika disesuaikan dengan 3.3 diperoleh rata-rata pencapaian aktivitas siswa pada siklus II berada dalam kategori sangat baik, dan bahwa untuk hasil observasi aktifitas guru mengalami peningkatan pada setiap pertemuan dengan rata-rata pencapaian pada siklus I sebesar 80. Perolehan ini jika disesuaikan dengan 3.3 diperoleh rata-rata pencapaian aktivitas guru pada siklus I berada dalam kategori sangat baik. Sedangkan rata-rata pencapaian pada siklus II sebesar 93,33. Perolehan ini jika disesuaikan dengan 3.3 diperoleh rata-rata pencapaian aktivitas guru pada siklus II berada dalam kategori sangat baik. Dalam kegiatan pembelajaran pada siklus II, guru telah berupaya memperbaiki penggunaan metode demonstrasi dalam menyampaikan materi gaya media yang ada sehinggah siswa mudah memahami materi gaya oleh Hasilnya siswa pun lebih fokus dan lebih menikmati pelajaran dengan baik. Peserta didik menjadi lebih aktif dan tidak malu lagi untuk bertanya mengenai materi yang belum dipahama. Siswa juga lebih mudah menjawab soal yang diberikan dengan bimbingan guru kepada siswa dengan baik. Berikut perbandingan hasil pembelajaran tahap pra siklus, siklus I dan siklus II dapat dilihat pada tabel berikut ini:

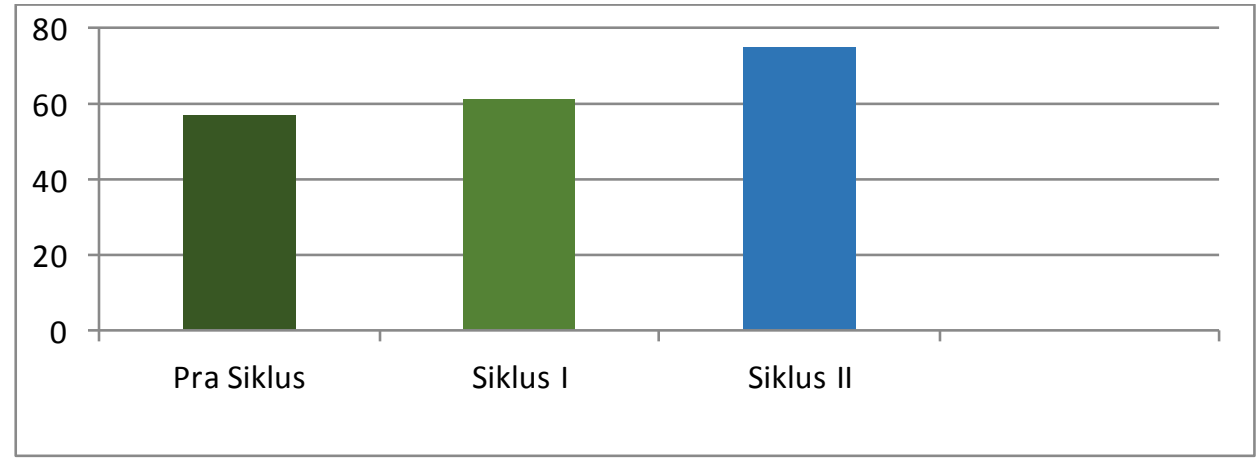

Diagram

Pra siklus, siklus I, Siklus II

Berdasarkan hasil pengamatan dengan penggunaan metode demonstrasi dapat meningkatkan hasil belajar IPA materi gaya pada siswa kelas V MI Yaminas 
Loppe Kabupaten Luwu. Hal ini dapat dilihat berdasarkan hasil tes siklus II menunjukkan peningkatan dengan rata-rata yaitu 75.67 dan ketuntasan belajar $86,67 \%$ atau dengan kata lain indikator yang ditetapkan sudah tercapai. Dengan demikian, tindakan pada siklus ini telah berhasil dan tidak perlu diadakan tindakan selanjutnya.

\section{E. Pembahasan}

Penelitian ini bertujuan untuk mengetahui apakah metode demonstrasi dapat meningkatkan hasil belajar IPA pada materi gaya siswa kelas V Madrasah Ibtidaiyah Yaminas Loppe Kabupaten Luwu. Adapun data yang diperoleh melalui instrument tes dan lembar observasi. Data yang diperoleh kemudian dianalisis melalui dua tahap yaitu uji coba instrument dan analisis data penelitian. Sebelum tes digunakan pada subyek penelitian, terlebih dahulu tes diuji validitas dan reliabilitas dengan menggunakan uji validitas isi dengan tujuan untuk melihat instrument yang digunakan layak atau tidak digunakan pada subyek penelitian.

Berdasarkan uji validitas diperoleh bahwa rata-rata penilaian instrumen tes siklus I sebesar 0,64 termasuk kategori "sedang/cukup" dan rata-rata penilaian instrumen tes siklus II sebesar 0,72 termasuk kategori "kuat/tinggi". Sedangkan berdasarkan uji reliabilitas menunjukkan bahwa tingkat kereliabelan tes siklus I sebesar 0,86 termasuk kategori "sangat tinggi" dan tes siklus II sebesar 0,92 termasuk kategori "sangat tinggi". Setelah tes dinyatakan valid dan reliabel, selanjutnya penulis melanjutkan pada tahap analisis data. diperoleh bahwa untuk hasil observasi aktifitas siswa mengalami peningkatan dari 76,51 pada siklus I menjadi 92,42 pada siklus II. Secara kategori meningkat dari baik menjadi snagat baik. Begitupun halnya dengan observasiaktivitas guru yang juga mengalami peningkatan yang dapat di lihat pada tabel 4.10 dan 4.11 dari 80 pada siklus I menjadi 93,33 pada siklus II. Secara kategori meningkat daribaik menjadi sangat baik. Dengan demikian, indikator observasi aktivitas siswa dan observasi aktivitas guru dalam penelitian tindakan kelas ini tercapai.

Berdasarkan rata-rata hasil tes pada siklus I diperoleh bahwa rata-rata sebesar 61 termasuk dalam kategori kurang. Sedangkan rata-rata hasil tes pada siklus II diperoleh bahwa rata-rata sebesar 75,67 termasuk dalam kategori cukup. Dengan demikian, indikator hasil belajar IPA dalam penelitian tindakan kelas ini tercapai. Ini berarti hasil belajar IPA siswa kelas V Madrasah Ibtidaiyah Yaminas Loppe Kabupaten Luwu pada materi gaya mengalami peningkatan melalui penerapan metode demonstrasi.

Perolehan hasil penelitian ini menunjukkan bahwa pembelajaran di sekolah tidak dapat dipisahkan dengan metode pembelajaran. Jika hasil belajar siswa kurang maksimal maka meto de yang digunakan dalam pembelajaran tidak efektif. Dalam ( Trianto,2015: 5) menyatakan bahwa yang di maksud dengan hasil belajar siswa adalah kemampuan yang diperoleh anak setelah melalui kegiatan belajar. Dalam pemelajaran harus memggunakan metode yang efektif sebagaimana (Roestiyah 2012:1) mengemukakan bahwa dalam proses belajar mengajar, guru harus memiliki strategi/metode, agar siswa dapat belajar secara efektif dan efisien, mengena pada tujuan yang diharapkan. Oleh karena itu, guru harus memperhatikan pemilihan metode yang tepat, efektif dan efisien dalam 
mengajar agar dapat membangkitkan minat dan motivasi belajar siswa, merangsang keinginan siswa untuk belajar lebih lanjut, memberikan kesempatan bagi siswa untuk mewujudkan hasil karya, menanamkan dan mengembangkan nilai-nilai dan sikap siswa dalam kehidupan sehari-hari, serta mendidik siswa untuk memperoleh pengetahuan melalui usaha sendiri.

Metode demonstrasi adalah metode mengajar dengan mempertunjukkan terjadinya suatu proses agar dapat diketahui dan dipahami oleh peserta didik secara nyata dengan tujuan untuk memperjelas konsep dan memperlihatkan secara langsung peristiwa yang sesuai dengan materi yang diajarkan.metode demonstrasi ini sangat memudahkan guru untuk menyampaikan materi ajar seperti dalam pembelajar IPA pada materi gaya karna dalam materi gaya dapat di demostrasikan atau mempraktekkan gambar materi gaya tersebut. (Mulyono, 2012: 86) mengemukakan bahwa metode demonstrasi merupakan metode yang sangat efektif sebab membantu peserta didik untuk mencari jawaban dengan usaha sendiri berdasarkan fakta atau data yang benar. Berdasarkan hasil penelitian menunjukkan penerapan metode demonstrasi dalam pembelajaran IPA khususnya materi gaya dapatmeningkatkan hasil belajar IPA. Hal ini didasari oleh keunggulan dari metode ini yaitu membuat pembelajaran menjadi jelas dan lebih konkrit, siswa lebih mudah memahami apa yang dipelajari, proses pembelajaran lebih menarik, serta siswa aktif mengamati, menyesuaikan antara teori dengan kenyataan, dan mencobanya melakukan sendiri. Selain itu, karena metode demonstrasi sangat menarik diterapkan bukan hanya pada mata pelajaran IPA, hal ini dikarenakan metode demonstrasi memiliki karakteristik dapat menunjukkan objek yang sebenarnya sehingga dapat memperjelas pengertian konsep, dan memperlihatkan cara melakukan sesuatu proses terjadinya sesuatu.

Selain itu, metode demonstrasi merupakan salah satu metode yang dianggap dapat mencapai tujuan pembelajaran IPA serta meningkatkan mutu pendidikan IPA. Hal ini karena melalui demonstrasi proses pembelajaran yang saling berinteraksi terlihat. Metode demonstrasi biasanya diikuti dengan pemberian kasus yang berfungsi untuk melatih pesrta dalam menemukan solusi dengan menggunakan kemampuan yang telah dilatihkan sebelumnya,(Ben ny A. Pribadi, 2014: 140). Mengajar bukan hanya menceritakan atau penuangan bahan pembelajaran kepada siswa. Proses pembelajaran akan menjadi aktif jika siswa terlibat langsung dalam penyelesaian semua masalah yang diberikan oleh gurunya. Untuk itu, semua siswa perlu mendengarnya, melihatnya, mengajukan pertanyaan tentang kompetensi yang sedang dibahas serta membahasnya dengan orang lain. Bahkan tidak cukup itu saja, melainkan siswa perlu mengerjakannya yakni menggambarkan sesuatu dengan caranya sendiri, menunjukkan contohnya, mencoba mempraktikkan keterampilannya dan mengerjakan tugas yang menuntut pengetahuan yang telah atau harus mereka dapatkan, menguasai konsep-konsep IPA dan keterkaitannya untuk dapat memecahkan masalah yang terkait dalam kehidupan sehari-hari. Menguasai konsep-konsep IPA mengisyaratkan bahwa pendidikan IPA harus dijadikan siswa tidak sekedar tahu dan hafal tentang konsep-konsep IPA melainkan harus 
dijadikan siswa untuk mengerti dan memahami konsep-konsep tersebut dan menghubungkan keterkaitan suatu konsep dengan konsep lain.

Dengan demikan, dalam menerapkan metode demostrasi, guru memperhatikan kondisi dan situasi dalam belajar siswa yang akan memberikan kesan yang mendalam bagi siswa dikarenakan guru telah memberikan pengalaman baik bagi yang mendemonstrasikan maupun bagi yang menyaksikan.

\section{F. Penutup}

Berdasarkan hasil penelitian dan pembahasan di atas, peneliti menyimpulkan bahwa penerapan metode demonstrasi pada mata pelajaran IPA pada materi gaya dapa tmeningkatkan hasil belajar siswa kelas V Madrasah Ibtidaiyah Yaminas Loppe Kabupaten Luwu. Hal ini ditunjukkan melalui perolehan hasil observasi aktivitas siswa dan guru serta hasi ltes yang menunjukkan terjadi peningkatan. Hasil observasiaktifitas siswa meningkat dari 76,51 pada siklus I menjadi 92,42 pada siklus II. Begitu pun halnya dengan observasi aktivitas guru juga meningkat dari 80 pada siklus I menjadi 93,33 pada siklus II. Baik padas iklus I dan II secara kategori menunjukkan adanya peningkatan secara kategori dari baik menjadi sangat baik. Sedangkan rata-rata hasil tes meningkat dari 61 termasuk dalam kategori kurang pada siklus I menjadi 75,67 termasuk dalam kategori cukup pada siklus II. Dengan demikian, indicator keberhasilan dalam penelitian tindakan kelas ini tercapai.

\section{DAFTAR PUSTAKA}

A Abitur. 2004. SAINS, Jakarta : Tropica.

Aqib Zainal.2010.Profesionalisme Guru dalam Pembelajaran. Surabaya: Insan Cendekia.

Arikunto Suharsimi. 2017. Dasar-dasar Evaluasi Pendidikan. Jakarta: Bumi Aksara.

Azwar Saifuddin. 2013. Reliabilitas dan Validitas. Yogyakarta: Pustaka Pelajar

Bahri Djamarah2006. Syaiful dan Aswan Zain. Strategi Belajar Mengajar. Jakarta: Rineka Cipta.

A. Benny. Pribadi, 2014 Desain dan pengembangan program pelatihan berbasis kompetensi.Jakarta : Prenada Media.

Fathurrohman Pupuh dan M. Sobry Sutikno. 2010. Strategi Belajar Mengajar. Bandung: Refika Aditama.

Jihad Asep dan Abdul Haris. 2013. Evaluasi Pembelajaran. (Cet.1; Yogyakarta: Multi Presindo.

Khanifatul. 2013. Pembelajaran Inovatif. Jogjakarta: Ar-Ruzz Media, Mulyono. Strategi Pembelajaran. Malang : UIN Maliki Press, 2012.

Muslich Masnur.2012.Melaksanakan PTK Itu Mudah (Classroom Action Research)

Pedoman Praktis bagi guru Profesional. Jakarta : Bumi Aksara.

Roestiyah. 2012. Strategi Belajar Mengajar. Jakarta: Rineka Cipta. 
Rustan, E. (2010). Pembelajaran Bahasa dan Sastra Daerah Berbasis Multikultural dalam Mewujudkan Pendidikan yang Berkarakter di Era Globalisasi. In Hanna, Firman, \& S. Safitri (Eds.), Kongres Internasional Bahasa-bahasa Daerah Sulawesi Tenggara (pp. 247-249). Baubau.

S Syamsu.2015.. Srategi Pembelajaran meningkatkan kompotensi guru . Makassar: Aksara Timur.

Sagala Syaiful. 2012. Konsep dan Makna Pembelajaran. Bandung : Alfabeta.

Sanjaya Wina. 2006. Srategi Pembelajaran Berorientasi Standar Proses Pendidikan. Jakarta : Kencana.

Slameto. 2013. Belajar dan Faktor-faktor yang Mempengaruhinya. Jakarta: Rineka Cipta

Sudiarditha Ketut R. , 2011. Guidance of Classroom Action Research In Professional Development (Penuntun Penelitian Tindakan Kelas dalam Pengembangan Profesi). (Jakarta:Bumi Timur Jaya

Sudijono Anas. 2017. Pengantar Statistik Pendidikan. Jakarta: RajaGrafindo Persada.

Sudjana Nana.2006.Penilaian Hasil Proses Belajar Mengajar. Bandung:Remaja Rosdakarya.

Suharsimi Arikunto. 2017. Dasar-dasar Evaluasi Pendidikan Jakarta: Bumi Aksara.

Susanto Ahmat.2016.Teori Belajar dan Pembelajaran Di Sekolah Dasar. Jakarta: Prenadamedia Grub.

Syamsu S. 2017.Strategi Pembelajaran : Tinjauan Teoritis Praktis Bagi Mahasiswa Dan Praktisi Pendidikan. Makassar : Nas Media Pustaka.

Trianto. 2015. Model Pembelajaran Terpadu. Jakarta : Bumi Aksara.

Uno Hamzah B. 2007. Model Pembelajaran. Jakarta: Bumi Aksara 